\section{Le Fort type 3 fracture or not?}

Vuk Aleksic ${ }^{1}$, Nenad Zivkovic ${ }^{1}$, Marko Samardzic ${ }^{1}$, Suzana Nedeljkovic ${ }^{2}$, Aleksandar Mitrovic ${ }^{3}$, Perica Jockic ${ }^{4}$, Stojanka Bandur ${ }^{2}$, Milenko Stanic ${ }^{1}$

${ }^{1}$ Department of Neurosurgery, Clinical-Hospital Center Zemun, Belgrade, Serbia

${ }^{2}$ Department of Radiology, Clinical-Hospital Center Zemun, Belgrade, Serbia

${ }^{3}$ Department of Surgery, Clinical-Hospital Center Zemun, Belgrade, Serbia

${ }^{4}$ Department of Urology, Clinical-Hospital Center Zemun, Belgrade, Serbia

\section{Abstract}

Axial non-contrast CT scan is the standard technique in patients with head and/or face injury. The three dimensional CT imaging reconstruction is becoming a gold standard in trauma of maxillofacial region enabling a clear perception of fracture lines and resulting displacement of fracture fragments. Le Fort fractures are fractures of the midface. In Le Fort type 3 fracture the craniofacial disjunction is present. A 91-yearold female had a mild facial trauma as a result of accidental fall. Axial CT scan showed artifacts, but three dimensional CT imaging reconstruction showed typical Le Fort type 3 fracture. Since clinical and 3D CT reconstruction finding were in complete contradiction, we repeated CT scan, which showed normal finding. This case is shows that in an era of incredible progress of neuroradiology, clinical examination still remains the best diagnostic tool.

Key words: Le Fort type 3, midface fractures, 3D CT;

\section{Le Fort 3 prelom ili ne?}

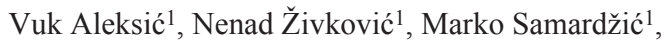
Suzana Nedeljković ${ }^{2}$, Aleksandar Mitrović ${ }^{3}$, Perica Jockić ${ }^{4}$, Stojanka Bandur ${ }^{2}$, Milenko Stanić ${ }^{1}$

${ }^{1}$ Služba Neurohirurgije, Kliničko Bolnički Centar Zemun, Beograd, Srbija

${ }^{2}$ Služba Radiologije, Kliničko Bolnički Centar Zemun, Beograd, Srbija

${ }^{3}$ Služba Hirurgije, Kliničko Bolnički Centar Zemun, Beograd, Srbija

${ }^{4}$ Služba Urologije, Kliničko Bolnički Centar Zemun, Beograd, Srbija

\section{Apstrakt}

Kod pacijenata sa povredom glave i/ili lica CT skener sa poprečnom projekcijom snimaka bez primene kontrasnog sredstva predstavlja standardnu dijagnostič$\mathrm{ku}$ proceduru. Trodimenzionalna rekonstrukcija slike kompjuterizovane tomografije postaje zlatni standard dijagnostike kod povrede maksilofacijalne regije, što omogućava jasni prikaz frakturnih linija, kao i položaj dislociranih koštanih fragmenata. Le Fort frakture predstavljaju fracture središnjeg dela lica. Kod Le Fort frakture tip 3, postoji specifično kranio-facijalno razdvajanje. Pacijentkinja, starosne dobi 91-u godinu primljena je zbog blage povrede lica usled zadesnog pada. CT skener sa aksijanom sekvencom pokazao je artefakte, ali je trodimenzionalna rekonstrukcija slike pokazala tipičan nalaz Le Fort tip 3 preloma. Kako su klinička slika i trodimenzionalna CT slika bile u kontradikciji, ponovili smo CT snimanje, koje je pokazalno uredan nalaz. Ovaj slučaj potvrđuje da u eri neverovatnog napretka neuroradiologije, kliničko ispitivanje i dalje predstavlja nezamenljiv dijagnostički postupak.

Ključne reči: Le Fort prelom tip 3; prelomi lica; 3D kompjuterizovana tomografija

\title{
Introduction
}

Head injury is the leading cause of morbidity and mortality in developing countries. Emergency departments rely on CT scans to manage trauma patients, especially for head injuries ${ }^{1}$. Axial non-contrast CT scan is the standard technique in victims with head/face injury, since fractures of the mid facial region are often difficult to diagnose on the conventional radiography because of complex anatomy of face and superimposition of thin bones of face which produce ghost artifacts leading to misinterpretation of fractures. The three dimensional CT imaging reconstruction (3D CT) is increasingly becoming a precious tool in trauma of maxillofacial region enabling a clear perception of the extent of major fracture lines and resulting displacement of fracture fragments ${ }^{2}$. Improved diagnosis of fracture lines and specific pattern of comminution in the mid face fractures is possible only with 3D CT. Three dimensional reconstruction allows an improved demonstration of displaced components of fractured fragments ${ }^{3}$. This new modality allows preoperative analysis and surgical planning 
as compared to conventional axial CT scan. Taking into account the above-stated, in our institution, the three dimensional head CT reconstruction is the method of choice for head and/or face injury patients.

Le Fort fractures are fractures of the midface, which collectively involve separation of all or a portion of the midface from the base of the skull. The Le Fort classification system attempts to distinguish according to the plane of injury. The frequently used classification has 3 types of midface fracture. In Le Fort type 3 fracture line passes through nasofrontal suture, maxillo-frontal suture, orbital wall and zygomatic arch, e.g. the craniofacial disjunction is present. The clinicians use a memory aid: "Le Fort type 3 represents a floating face" (separation of the entire bony face from the cranial base). The numerous components seen in the Le Fort fractures make classification difficult, and each of the Le Fort fractures has at least one unique component that is easily recognizable: Le Fort type 3 includes fracture of zygomatic arch ${ }^{4}$. However, there can also be other fracture lines present, with multiple fragments, so every patient is a unique case.

Clinical examination along with the $\mathrm{CT}$ is a gold standard in the diagnosis and treatment planning of head and maxillofacial injuries.

\section{Case presentsation}

A 91-year-old female was admitted to our Emergency Neurosurgical Department following a mild facial trauma as a result of accidental fall at home. There was no history of loss of consciousness and vomiting. She complained on headache. Beside the signs of light cognitive impairment due to dementia, neurological examination was completely normal. Physical examination showed only small abrasions on the facial skin in the zygomatic region on the both sides. Mouth opening, as well as intraoral examination was normal. There were no step defects, neither any specific sign of facial bone fractures. Patient was sent for emergency CT of the head with the three dimensional reconstruction, which is a standard procedure in our clinic for head/face victims. 3D CT reconstruction showed a separation of the entire bony face from the cranial base, e.g. the Le Fort type 3 fracture, with fracture line extending from nasofrontal suture to maxilofrontal suture, thorough orbit to zygomatic arches on both sides (Figure 1.).

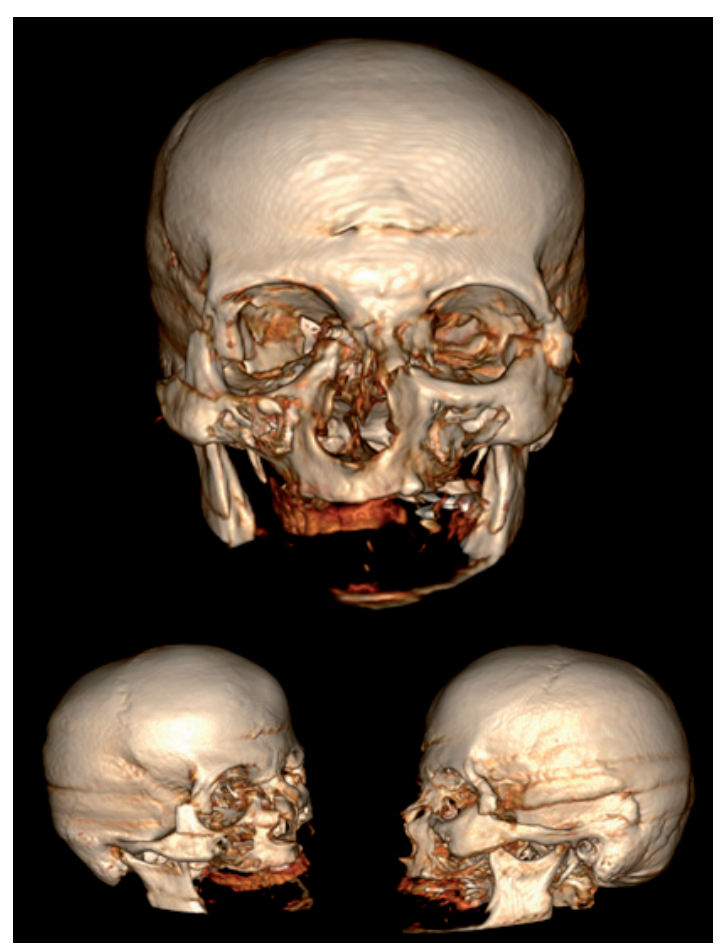

Figure 1. The three dimensional CT imaging reconstruction with typical finding of Le Fort type 3 skull fracture. 


\section{CASE REPORTS}

Since clinical and 3D CT reconstruction finding were in complete contradiction, and axial CT scan showed artifacts (Figure 2.), we were confused, and thus repeated CT scan, which showed normal finding (Figure 3.), so the signs of fracture were interpreted as artifacts due to patient movement during first CT investigation.

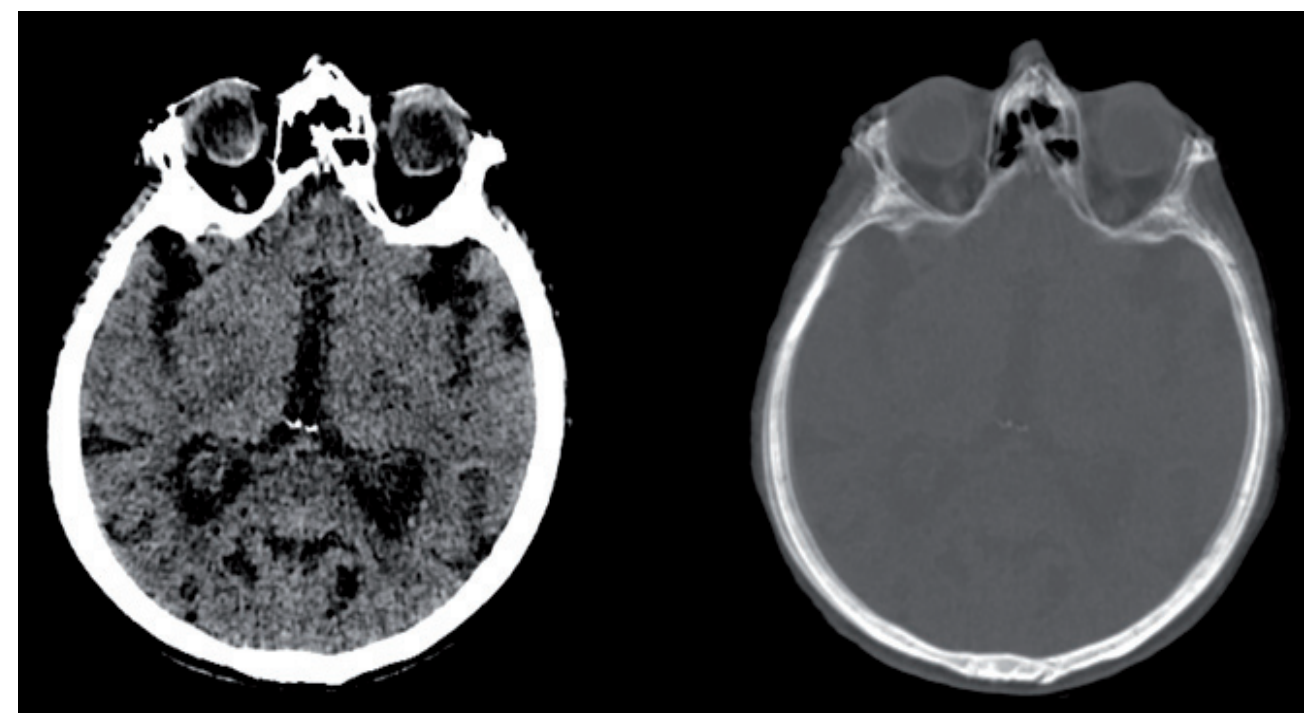

Figure 2. Axial CT scan showing artifacts

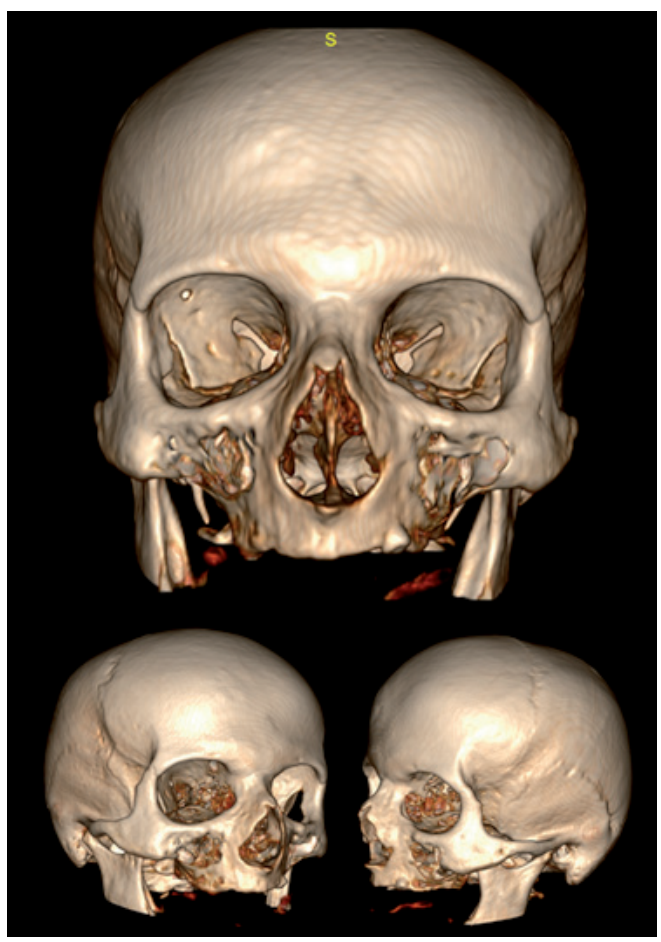

Figure 3. The control three dimensional CT imaging reconstruction presenting normal finding.

Patient resaved analgesics and after a few hours of hospital observation patient was discharged from hospital. Written informed consent for the publication of this case report and accompanying images was obtained from the patient. 


\section{Discussion and conclusion}

Head injury, often associated with facial trauma, is the leading cause of morbidity, mortality, disability and socioeconomic losses in developing countries. Every year in India, about 2 million people are injured with about 1 million deaths due to head injury. About $60 \%$ of the total cases are due to road traffic accidents, followed by falls, and violence ${ }^{1,5}$. We report a case of elderly female, injured by accidental fall at home, who suffered small bilateral facial abrasions. CT scan is the primary screening modality of investigations in head/ face trauma victims ${ }^{1,6}$. The merits of CT for evaluation of head injury are its sensitivity for demonstrating bone injuries apart from acute hemorrhage, mass effect, ventricular configuration and size ${ }^{1,7}$. The three dimensional computed tomography reconstruction is increasingly becoming a valuable tool in maxillofacial trauma $^{2}$. In our clinic, head CT with three dimensional reconstruction is crucial diagnostic tool in patients with head/face injury. We presented a case of patient with mild facial trauma and confusing finding on first 3D head CT finding, with typical presentation of Le Fort type 3 fracture of the skull. Although axial CT suggested artifacts, 3D reconstruction image was so indicative for Le Fort type 3 fracture, so we decided to perform control CT scan, which showed normal finding. This case is illustrative that in an era of incredible and vertiginous progress of neuroradiology, clinical examination still remains the best diagnostic tool.

\section{Literature}

1. Chawla H, Yadav RK, Griwan MS, Malhotra R, Paliwal PK. Sensitivity and specificity of CT scan in reveling skull fracture in medico-legal head injury victims. Australas Med J 2015; 8: 235-8.

2. Kaur J, Chopra R, Three Dimensional CT Reconstruction for the Evaluation and Surgical Planning of Mid Face Fractures: A 100 Case Study. Maxillofac Oral Surg 2010; 9(4):323-8.

3. Levy RA, Kellman RM, Rosenbaum AE. The effect of computed tomographic scan orientation on information loss in the three-dimensional reconstruction of tripod zygomatic fractures. Invest Radiol 1991; 26(5):427-31.

4. Rhea JT, Novelline RA. How to simplify the CT diagnosis of Le Fort fractures. AJR AM J Roentgenol 2005; 184(5):1700-5.

5. Gururaj G. Epidemiology of traumatic brain injuries: Indian scenario. Neurol Res 2002; 24(1):24-8.

6. Tress BM. The need for skull radiography in patients presenting for CT. Radiology 1983; 146(1): 87-9.

7. Davis PC, Expert Panel on Neurologic Imaging. Head trauma. AJNR Am J Neuroradiol 2007; 28(8):1619-21.

Autor za korespodenciju:

Vuk Aleksić

Služba Neurohirurgije, Kliničko Bolnički Centar Zemun, Beograd, Srbija

Vukova 9, Zemun, Beograd

Telefon: +381652207845

Email: aleksicvuk@hotmail.com 